\title{
Qualitative and anatomical characteristics of tree-shrub legumes in the Forest Zone in Pernambuco state, Brazil ${ }^{1}$
}

\author{
Mônica Alixandrina da Silva², Mércia Virginia Ferreira dos Santos ${ }^{3}$, Mario de Andrade Lira ${ }^{4}$, \\ José Carlos Batista Dubeux Júnior ${ }^{3}$, Dulciene Karla de Andrade Silva ${ }^{3}$, Kleber Régis Santoro ${ }^{3}$, \\ Paulo Marcio Barbosa de Arruda Leite ${ }^{5}$, Erinaldo Viana de Freitas ${ }^{6}$
}

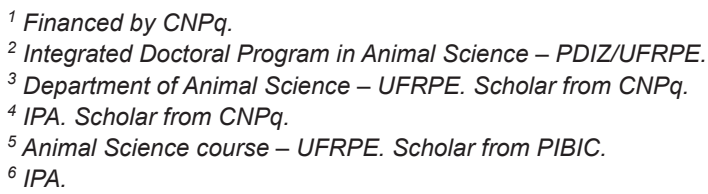

ABSTRACT - The objective of this study was to characterize the nutritional value of forage legumes Mimosa caesalpiniifolia (Benth.), Bauhinia cheilantha (Bong.) and Leucaena leucocephala (Lan.) and evaluate the anatomy of plants incubated and not incubated in the rumen. The experiment was conducted from September 2007 to November 2008. The experimental plot consisted of three useful plants, totaling three plots per block, and four repetitions. Plants were cut at $1 \mathrm{~m}$ height at intervals of 70 days; samples of leaf plus stem with a diameter smaller than $4 \mathrm{~mm}$ were collected for determination of dry matter, crude protein, neutral detergent fiber, acid detergent fiber, insoluble protein bound to acid detergent fiber and in vitro dry matter digestibility. The anatomical characterization occurred through the analysis of the proportion of plant tissue nonincubated and incubated in the rumen for a period of 48 hours. The legumes had high crude protein, with an average of $26.1 \%$ to Leucena, $22.4 \%$ to Sabiá and $18.5 \%$ to Mororó, and low levels of in vitro digestibility of dry matter, with an average of $47.3 \%$ to Leucena, $42.8 \%$ to Mororó and $37.2 \%$ to Sabiá. In the leaf blade of Sabiá plants, much lignified tissues that differed from plants of Leucena and Mororó were observed. The degradation process was more visible in the leaves of the Leucena, Sabiá and Mororó plants. The degradation was more pronounced in the spongy parenchyma, leaving the incubated material intact. The average proportion of the epidermis in the incubated and not incubated leaves was 15.8 and $16.4 \%$ in Leucena, 16.8 and $19.2 \%$ in Mororó and 27.2 and 25.5\% in Sabiá, respectively. There are differences in the digestion and nutritional value of leaf tissues of the evaluated legumes.

Key Words: anatomy, chemical composition, degradability, native forage

\section{Introduction}

The region of Zona da Mata of Pernambuco, Brazil, has the cultivation of sugar cane as a predominant activity. However, cattle raising is a major concern because, in addition to the proximity to the consumer market, factors such as rainfall, temperature and luminosity are very favorable to the cultivation of pasture. However, these favorable conditions, during the dry season, cannot prevent the decreased availability and quality of forage from damaging mainly the growing animals, whose requirement is quite high (Cavalcanti Filho et al., 2008).

According to Kozloski et al. (2003), the main constraint to the cattle raising activity in the tropics is presented by the low quality of most tropical grasses, especially in monoculture systems. Thus, to increase the quality of the diet supplied to the animals, an alternative recommended is the adoption of legumes because of their high protein content. However, to contribute to the optimization of the animal feed and also support selection of materials, it is important to know the chemical composition and digestibility of forage legumes.

Besides the chemical composition, the quantitative plant anatomy represents an interesting complementary tool for studies evaluating the quality of forage, since research has demonstrated the occurrence of an association between the tissue anatomy and quality of forage (Brito et al., 1997; Ventrella et al., 1997; Brito et al., 2004; Lempp, 2007). The digestibility of a forage is closely related to the arrangement of tissues and their bromatologic composition (Lima et al., 2001), as well as the different types and percentages of tissues, organs and age of the plant, allowing differentiation of these nutritional plants (Brito et al., 1997; Soffiatti \& Angyalossy, 2003).

The objective of this study was to characterize the anatomy of the bromatological chemical composition and 
the in situ degradability of the tissues of forage legumes Leucena, Mororó and Sabiá.

\section{Material and Methods}

The experiment was conducted at Instituto Agronômico de Pernambuco (IPA), at the Itambé Experimental Station, located in Zona da Mata Seca, in the State of Pernambuco, at $190 \mathrm{~m}$ altitude (CPRH, 2003). The experimental period was from September 2007 to November 2008, with cumulative rainfall of 1,300 $\mathrm{mm}$ (Figure 1).

The experimental treatments were composed of forage legumes Leucena (Leucaena leucocephala (Lan), de Wit), Mororó (Bauhinia cheilantha (Bong.), Steud) and Sabiá (Mimosa caesalpiniifolia (Benth.)), randomly arranged in four blocks per treatment, evaluated during five periods in a randomized block design, following the model of repeated measures in time.

The total experimental area was $288 \mathrm{~m}^{2}$, with four blocks of $72 \mathrm{~m}^{2}$, and each species included an experimental plot with $24 \mathrm{~m}^{2}$, considering the plants presenting borders as useful plants in the plot, i.e., plants completely surrounded by other plants, comprising three useful plants per plot, totaling 12 plants per species in the experimental area.

In September 2007, a cut of standardization was performed, and every 70 days useful plants were cut at $1 \mathrm{~m}$ height from the ground; five cuts were made. At every cut, samples of leaves and stems with diameters smaller than $4 \mathrm{~mm}$ were collected to determine the bromatological chemical composition and in vitro dry matter digestibility. Dry matter $(\mathrm{DM})$, crude protein (CP), neutral detergent fiber (NDF), acid detergent fiber (ADF) and insoluble protein bound to acid detergent fiber (ADF) were analyzed at the Laboratory of Food Analyses of Unidade Acadêmica de Garanhuns - Universidade Federal Rural de Pernambuco, Campus Garanhuns, according to the methodology described by Silva \& Queiroz (2002). The analysis of in vitro dry matter digestibility (IVDMD) was performed at Laboratório da Embrapa Semiárido - Petrolina (Laboratory of Semi-Arid EMBRAPA in Petrolina, Pernambuco, Brazil), according to the methodology described by Tilley \& Terry (1963).

In the last period of assessment of the three legumes (November 2008), samples were collected for anatomical characterization of plants. This occurred through the fifth leaf of the representative branch of the plant, which was chosen at random, conditioned in airtight containers and taken to the laboratory. Squares of $1 \mathrm{~cm}^{2}$ were cut from the leave at each end, fixed in FAA (formalin solution, acetic acid and $70 \%$ alcohol). Then, the in situ degradability assay was performed, in the goat sector of the Department of Animal Science, where the rumens of two goats were used. These animals underwent an adaptation period of 3 days with a diet similar to the material incubated in the rumen (composed of leaves and branches (diameter smaller than $4 \mathrm{~mm}$ ) of Sabiá plants) during the experimental period. The sample, previously stored in FAA, was placed into a silicone tube of $1 \mathrm{~mm}$ thickness and closed in nylon bags, previously identified according to the methodology described by França et al. (2010). Thereafter, all samples of the three legumes were incubated in the rumen for a period of 48 hours. After the incubation period, this material was removed and washed in running water and then in distilled water, and fixed in FAA at $70 \%$.

The anatomical study was carried out at the Laboratory of Forage Plant Anatomy of the Department of Animal Science of Universidade Federal Rural de Pernambuco. The cross sections of the leaf blade were made by using a rotary microtome, obtaining 10 slices of $7 \mathrm{~mm}$ thickness for the sample of each species, stained by triarch quadruple stain for visualization of lignified tissues (Hagquist, 1974), enabling the quantification of different types of tissues, through measurements obtained in the middle portion between the midrib and the edge of the leaf. After selection of the best blades, photographs were taken with photomicroscope Olympus BX41.

The data for the chemical composition were analyzed by using the MIXED procedure of SAS (Statistical Analysis System, version 9.0) for Windows, using a model for analysis of repeated measures in time with contrast test for determining the averages. A descriptive statistic was conducted for data related to the histology of the tissues of forage legumes.

\section{Results and Discussion}

Significant differences were observed $(\mathrm{P}<0.05)$ for most of the chemical components evaluated in Sabiá, Leucena and Mororó (Table 1) and for DM in the five periods of observation only in the Sabiá and Mororó plants. These oscillations in DM may be associated with rainfall conditions in the region, as noted by Caldas et al. (2010), who, evaluating the dry matter content in the Sabiá plants at 12 years of age, observed significant differences between the rainy and dry seasons, with averages of 43.0 and $30.2 \%$, respectively.

The lack of significance for DM among the evaluation periods in the Leucena plants can be associated with the adaptability of this legume to the Forest Zone (Zona da Mata), which is characterized by better distribution of rainfall. Other studies in the literature (Pereira et al., 2004) 
Table 1 - Chemical composition of legumes at 70 days of age in Pernambuco, Brazil

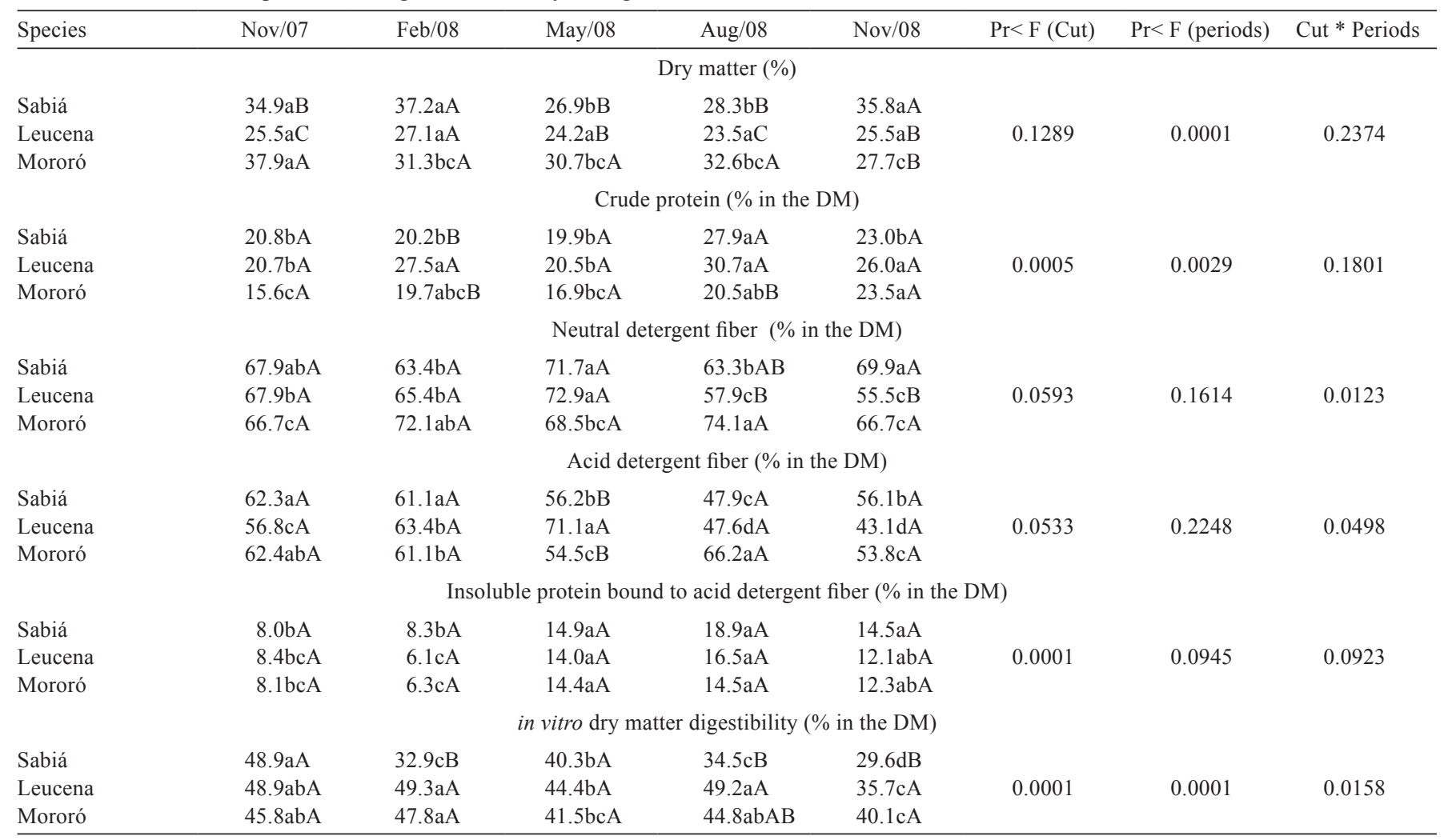

Means followed by the same letter in the row for cut and column for species do not differ $(\mathrm{P}>0.05)$ by the SNK test.

DM - dry matter.

also demonstrated, in the Leucena plants, average levels of $27 \%$ of dry matter with a sample composed of leaves and branches. The composition of this material, in addition to the edaphoclimatic conditions inherent to the species itself, can be one of the factors that determine the amount of water. Thus, one can infer that in future studies of selection, one must consider the low variability of this trait in young plants.

The Mororó plants presented high dry matter content in the month of November/07, compared with the other evaluation periods, because it is a time with little available water for the plant (Figure 1). Thus, besides the period of the year, one can observe that the climatic conditions in different regions also interfere in the dry matter content, according to data presented by Moreira et al. (2006) in the Caatinga ( $46.8 \% \mathrm{DM})$, which were higher than those observed in this study because of the low water availability in the Caatinga region.

The three legumes of this study showed crude protein content above $16 \%$ and low concentrations of acid detergent insoluble protein (ADIP), which indicates the potential of these species for use in the feeding of small ruminants. According to Van Soest et al. (1994), protein levels below $7 \%$ in the diet can impair ruminal fermentation, and result in negative balance of nitrogen.

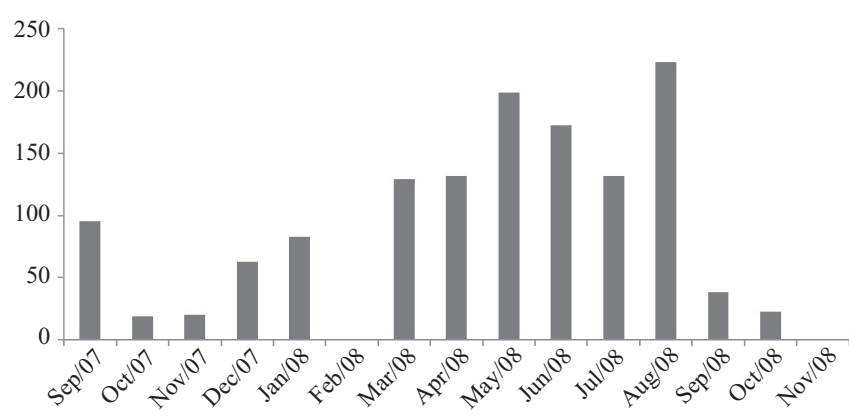

Figure 1 - Precipitation (in millimiters) during the trial period in Itambé, Pernambuco.

The rainy season leads to higher values of crude protein in relation to the dry season, as noted by Caldas et al. (2010), who found $16.7 \%$ in the dry season and $22.1 \%$ in the rainy season. These authors attributed this to greater photosynthetic activity enabled by the increase in water availability, which increases the biological fixation of nitrogen.

The crude protein values observed in this study were high, due to the greater number of leaves in relation to the branches in the evaluated samples. This indicates that the 
quantification of the number of leaves is important because it reflects how the plant can be more nutritious, in addition to being an indicator of their increased productivity. Therefore, the number of leaves present in the plant is related with increased dry matter production in the Sabiá and Mororó plants.

There was no significant difference $(\mathrm{P}>0.05)$ between the Leucena plants and the native legumes of Mororó and Sabiá, as to the levels of crude protein, except for February and August $/ 08$, presenting variations according to the time of assessment, with the highest crude protein content $(30 \%)$ in the rainy season observed in Leucena. This lack of significance among the three species can be correlated to the fact that they are in the same edaphoclimatic conditions.

The response of the most qualitative variables of Mororó and Sabiá native legumes were similar to the Leucena plant, according to the data observed for crude protein. But just like Leucena, the Mororó and Sabiá plants had an average of $11.1 \%$ and $14.1 \%$ from the total of this protein, respectively, linked to the acid detergent fiber (Table 1), indicating that only part of the protein was available to the animal. The literature (Vieira et al., 2005; Goyanna, 2009) expressed similar data of ADIP for these two native species, indicating that this trait may have a greater correlation with the genetics of these plants than with the environment itself.

There were no significant differences $(\mathrm{P}>0.05)$ for NDF between the three legumes in November/07 and May/08 (Table 2). For the other evaluation periods, the Mororó

Table 2 - Chemical composition as a function of the cut period $\times$ species interaction in three forage legumes in the municipality of Itambé, Pernambuco

\begin{tabular}{lcccc}
\hline \multirow{2}{*}{ Cut } & & \multicolumn{3}{c}{$\%$ in DM } \\
\cline { 3 - 5 } November/07 & Species & NDF & ADF & IVDMD \\
\cline { 3 - 5 } & Leucena & $67.9 \mathrm{a}$ & $62.3 \mathrm{a}$ & $48.9 \mathrm{a}$ \\
& Mororó & $67.9 \mathrm{a}$ & $56.8 \mathrm{~b}$ & $48.9 \mathrm{a}$ \\
February/08 & Sabiá & $63.4 \mathrm{~b}$ & $62.4 \mathrm{a}$ & $45.8 \mathrm{a}$ \\
& Leucena & $65.4 \mathrm{~b}$ & $63.4 \mathrm{a}$ & $49.3 \mathrm{a}$ \\
& Mororó & $72.1 \mathrm{a}$ & $61.1 \mathrm{a}$ & $47.8 \mathrm{a}$ \\
May/08 & Sabiá & $71.7 \mathrm{a}$ & $56.2 \mathrm{~b}$ & $40.3 \mathrm{a}$ \\
& Leucena & $71.1 \mathrm{a}$ & $71.1 \mathrm{a}$ & $44.4 \mathrm{a}$ \\
August/08 & Mororó & $68.5 \mathrm{a}$ & $54.5 \mathrm{~b}$ & $41.5 \mathrm{a}$ \\
& Sabiá & $63.3 \mathrm{~b}$ & $47.9 \mathrm{~b}$ & $34.5 \mathrm{~b}$ \\
& Leucena & $57.9 \mathrm{c}$ & $47.6 \mathrm{~b}$ & $49.2 \mathrm{a}$ \\
November/08 & Mororó & $74.1 \mathrm{a}$ & $66.2 \mathrm{a}$ & $44.8 \mathrm{a}$ \\
& Sabiá & $69.9 \mathrm{a}$ & $56.1 \mathrm{a}$ & $29.6 \mathrm{c}$ \\
& Leucena & $55.5 \mathrm{~b}$ & $43.1 \mathrm{~b}$ & $35.7 \mathrm{~b}$ \\
& Mororó & $66.7 \mathrm{a}$ & $53.8 \mathrm{a}$ & $40.1 \mathrm{a}$ \\
\hline
\end{tabular}

Means followed by the same letter in the column do not differ $(\mathrm{P}>0.05)$ by the SNK test.

DM - dry matter; NDF - neutral detergent fiber; ADF - acid detergent fiber; IVDMD - in vitro dry matter digestibility. plants stood out for having the highest NDF, followed by Sabiá plants and sequentially by the Leucena plants. The results for the NDF were on average above $60 \%$, indicating that the limitation of the dry matter intake may occur due to the high concentration of this chemical component, causing the filling of the rumen.

Legumes were similar within the cuts, especially for crude protein. These results indicate that fertility of the soil simultaneously with the rainfall conditions is important not only for its structural development, but also for determining the quality of these species. Thus, it was observed that concerning dry matter and crude protein, due to the behavior during the cutting period, there was no interaction with the species (Table 2).

The three legumes showed high levels of ADF, indicating that it is one of the possible reasons for the low digestibility of these species in this study. The literature has pointed the reduction in digestibility in forage grasses (Paciullo et al., 2001), due to increased NDF and ADF, and the same behavior has also been observed in legumes (Aviz et al., 2009; Gobbi et al., 2010).

There were significant differences for the ADF content between the cutting times, except for May/08. These results indicate that although the plants present the same chronological age, the physiological variation between the ages of plants may have occurred, which is an agenetic characteristic of each material. However, although the genetic load influences the differentiation between species, the same cannot happen within the same species. As demonstrated in this study, some variables were similar to Goyanna (2009). However, these authors worked with fresh plants and plants transformed in hay in semiarid conditions, indicating that the genetic factor may lead to one result, but the soil and edaphoclimatic conditions may alter this result.

No significant differences were observed $(\mathrm{P}>0.05)$ for the IVDMD levels between the three forages (Table 2). In November/07 and May/08, however, the Sabiá plants in other evaluation periods showed the lowest levels of IVDMD, indicating that this species may present tissues of difficult digestion, with high concentrations of lignin, thus hindering their degradability. Furthermore, plants adapted to drought conditions (Xerophytes), such as Sabiá, have high concentration of cutin in their epidermis, which can hinder the degradation process.

The IVDMD observed in this study refers to samples composed of leaves and branches. The results were inferior to those observed by Goyanna (2009), who worked with samples containing only leaves and obtained levels of $67.9 \%$ for the Mororó plants and $66.5 \%$ for the Sabiá plants. 
However, they found values close to this study, as observed by Moreira et al. (2006) in the Mororó plants. Based on this, one can infer that the way the chemical composition of the species evaluated can affect the results.

Given the above, although the results are considered low for IVDMD, this is also an indication that legumes have constituents which are difficult to digest or factors that hinder this. Some studies suggest an association of histology with digestibility in order to try to explain these low levels. In agreement with these results, the exposed material for anatomical evaluation of these legumes did not show good degradation in the rumen (Figure 4). Legumes such as Sabiá and Mororó showed juxtaposed tissues, making access to the tissues of organisms difficult; this is a possible explanation for the low digestibility (Table 2).

Tissues with difficult digestion like the vascular bundles and xylem were in smaller proportions in legumes in relation to the tissues with high potential for digestion, like the palisade and spongy parenchyma (Table 3). However, the values for the parenchyma palisade with the leaves with no incubation did not differ from the incubated leaves, like the epidermis, indicating that when there was degradation of the sheets, the degradation was higher in the spongy parenchyma and lower epidermis, due to its wall, which is thinner than the adaxial epidermis.

The plants evaluated in this study were collected in the dry season, in an advanced stage of maturity, with greater lignification of the cell wall, which resulted in lower degradation of leaves, although they were incubated for a period of 48 hours, which is, according to Akin et al. (1989), long enough for the attack of the microorganisms in the material incubated at rumen level, mainly in the mesophyll cells and phloem, which had already completed total digestion in 12 to 24 hours.

Lack of physical damage in the material incubated in the rumen, due to protection of silicone tubes, may have been the factor of low degradation of the leaves of legumes, since the food chewing via animal is an important tool to facilitate the access of microorganisms to mesophyll cells and their cellular content. Although the injury via stomata is important for the access of the rumen microorganisms, Brito et al. (1999) stated that tearing by chewing and rumination is more important because they minimize the effect of the barrier imposed by the epidermis and cuticle, and also to break the cells individually.

The tissue digestion of legumes was different according to their location, starting in spongy parenchyma due to the presence of parenchyma, facilitating the access to the cellular content of microorganisms. This tissue was found in a higher proportion of the Leucena and Sabiá incubated plants, which may have facilitated the degradation process of these plants (Table 3).

One reason for the degradation to start in the region of spongy parenchyma is the smaller cell size of the lower epidermis, which is why there is a greater presence of intercellular spaces in this region, since the cells that are in the adaxial region are larger and have greater structural strength. Thus, the reason why organisms access the abaxial region of the leaf are the stomata and the epidermis and, which presents smaller size and therefore less resistance.

Table 3 - Proportion of legume leaf tissues unincubated and incubated for 48 hours

\begin{tabular}{|c|c|c|c|c|c|c|}
\hline \multirow{2}{*}{ Variables } & \multicolumn{3}{|c|}{ Unincubated plants } & \multicolumn{3}{|c|}{ Incubated plants } \\
\hline & Mean (\%) & Standard deviation & Confidence interval* & Mean (\%) & Standard deviation & Confidence interval* \\
\hline \multicolumn{7}{|c|}{ Leucena } \\
\hline Phloem & 1.6 & 0.4 & 0.6 & 2.4 & 1.4 & 1.9 \\
\hline Xylem & 9.2 & 1.9 & 2.6 & 7.7 & 2.9 & 4.1 \\
\hline Epidermis & 15.8 & 1.3 & 1.9 & 16.4 & 0.5 & 0.7 \\
\hline Parenchyma & 66.1 & 1.2 & 1.7 & 59.3 & 2.5 & 3.4 \\
\hline Gaps & 7.1 & 0.3 & 0.4 & 14.2 & 7.4 & 10.2 \\
\hline \multicolumn{7}{|c|}{ Mororó } \\
\hline Phloem & 1.7 & 0.5 & 0.4 & 1.6 & 0.8 & 0.7 \\
\hline Xylem & 9.1 & 1.6 & 1.4 & 9.3 & 5.1 & 4.5 \\
\hline Epidermis & 16.8 & 3.9 & 3.5 & 19.2 & 5.7 & 5.0 \\
\hline Parenchyma & 65.1 & 3.8 & 3.3 & 63.5 & 6.2 & 5.4 \\
\hline Gaps & 7.2 & 1.7 & 1.5 & 6.4 & 2.1 & 1.9 \\
\hline \multicolumn{7}{|c|}{ Sabiá } \\
\hline Phloem & 0.7 & 0.2 & 0.2 & 0.7 & 0.4 & 0.4 \\
\hline Xylem & 4.1 & 1.7 & 1.7 & 4.3 & 2.7 & 2.6 \\
\hline Epidermis & 27.2 & 1.7 & 1.6 & 25.5 & 3.9 & 3.9 \\
\hline Parenchyma & 60.0 & 0.9 & 0.9 & 57.8 & 15.8 & 15.5 \\
\hline Gaps & 7.9 & 1.5 & 1.4 & 11.5 & 10.0 & 9.8 \\
\hline
\end{tabular}

* At $5 \%$ of probability. 
Drought-resistant plants are characterized by the location of the stomata in the lower epidermis, as well as thicker adaxial epidermis and a larger number of cuticles, as a protection against water loss and predators. In this study, it was observed that Leucena showed such features, since the stomata were in greater quantity in the abaxial region of the leaf, and the lower epidermis was less thick than the adaxial, facilitating the entry of microorganisms in this region (Figure 2A,B).

The arrangement of the leaf tissues favors the presence of microorganisms in a given region, since after the adaxial epidermis is where the palisade parenchyma is found, which extends to the center of the limbo, where the mesophyll cells are inserted, from the parenchyma sheath and vascular bundles. In the lower region there are the spongy parenchyma and lower epidermis, highlighting the presence of microorganisms in this region due to the facility of access via the epidermis.
In the Leucena plants, it was observed that the palisade parenchyma appeared well juxtaposed, with little variation in size, without many intercellular spaces, but mostly with only one layer, which may have facilitated the translocation of microorganisms from the adaxial epidermis to the mesophyll. The size variation of the palisade parenchyma may have contributed to formation of aerenchyma, allowing more space for the transit of microorganisms (Figure 2). Moreover, the leaves of Leucena had higher proportion of secondary beams (phloem) which may have promoted further degradation of the plant, since they are easily digested tissues.

The palisade parenchyma cells, in the leaves of Mororó, showed small size, but with up to three layers (Figure 3A). The first layer located below the adaxial epidermal cells exhibited more juxtaposed cells with fewer intercellular spaces; the spaces in the second layer were at greater proportion, increasing in the third layer, with a dilation of

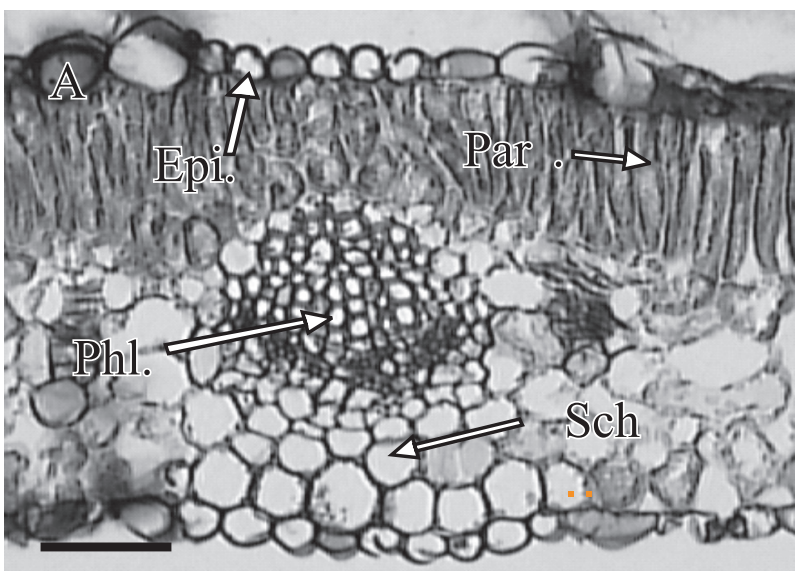

Par. - parenchyma; Sch. - sclerenchyma; Phl. - phloem; Epi. - epidermis. Bar $=10 \mu \mathrm{m}$.

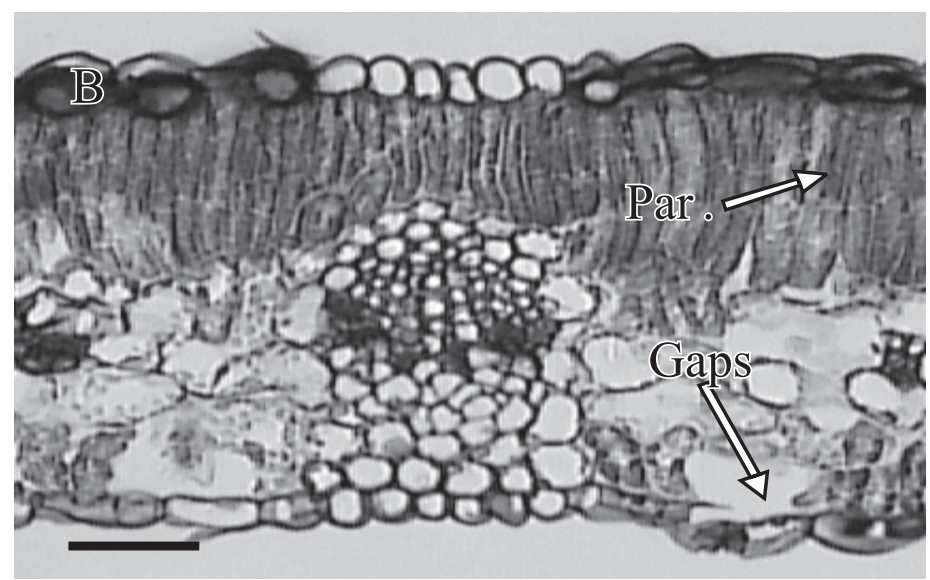

Figure 2 - Photomicrograph of the cross section of the leaf of unincubated Leucena plants (A) and of Leucena plants incubated for 48 hours (B).
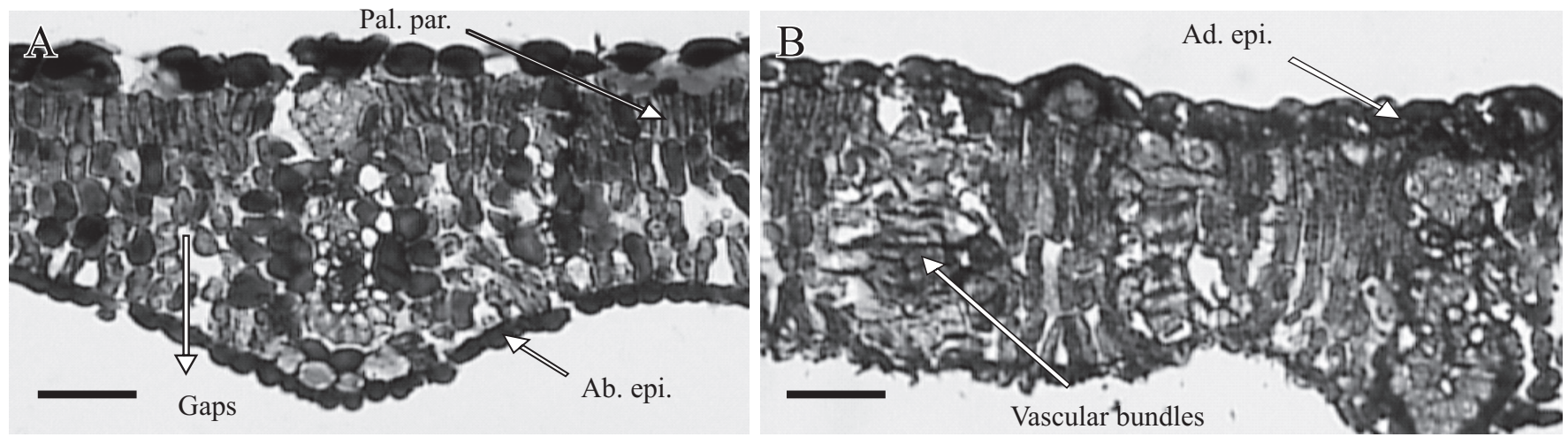

Pal. par. - palisade parenchyma; Ab. epi. - abaxial epidermis; Ad. epi. - adaxial epidermis.

$\mathrm{Bar}=10 \mu \mathrm{m}$.

Figure 3 - Photomicrograph of the cross-section of the leaf of unincubated Mororó plants (A) and of Mororó plants incubated for 48 hours (B). 
the layers from the periphery to the center of the limbus. This arrangement of the parenchyma in the leaves explains why the central cells degrade more easily.

Regarding incubated plants, despite the time imposed to them, the samples of Mororó were practically unchanged, both the vascular bundles, and the parenchymal cells (Figure 3A). Their cells were shown to be fair in the palisade parenchyma, and with the presence of many layers, which may have inhibited the access of microorganisms, making the degradability of these plants difficult. In addition to the arrangement of tissues, the Mororo plants showed high levels of NDF (Table 2), which is associated with the sampling period, and which may have favored increased lignification of the cell wall through the secondary wall thickening.

According to the literature (Wilson, 1993; Paciullo, 2002), when the cells are loosely arranged in the parenchyma, they allow rumen microorganisms to quickly access the cell walls, promoting a high rate of digestion and also facilitating fragmentation of the tissues through physical processes such as chewing. This occurs because the aerenchyma forms lacunae from the disruption of the parenchyma cells.

In the incubated plants of Mororó, there was a large proportion of undifferentiated tissue in the cells of the spongy parenchyma, whose action of microorganisms, or the paradermal cuts was difficult to assign (Figure 3B). As in this study, Silva (2010) also observed undifferentiated tissues in the parenchyma, working with the orelha-deonça legume after incubation for 48 hours, reporting that the measurements in degraded areas were made difficult by these tissues.

Regarding the epidermis of the Mororó plants, these cells showed larger adaxial cells, highlighting the secondary beams that are long and are understood from the adaxial part of the epidermis to the lower epidermis, preventing the continuation of parenchymal cells (Figure 3A,B). This feature hinders the traffic of microorganisms between the mesophyll cells, impairing the plant digestion, since the mesophyll cells are highly digestible, especially in legumes (Akin, 1989).

There was a low degradation of the Mororó incubated leaves, which occurred in greater proportion in the phloem and spongy parenchyma, via the lower epidermis, due to its smaller thickness (Figure 3B). According to Chesson et al. (1986) the mesophyll cells are easily fragmented into small particles, being quickly and completely digested. This digestion starts in these cells up to the phloem, which has only a thin primary non-lignified wall (Hanna et al., 1973; Akin et al., 1973).

The Sabiá plants showed palisade parenchyma cells with two layers, greater intercellular spaces, little juxtaposed and with a small amount of vascular bundles. This lesser juxtaposition conditioned the greater movement of the microorganisms, thus resulting in the digestion process (Figure 4A,B).

Some legumes may have similar organization of tissues, as described by Silva (2010), when analyzing the orelha-de-onça legume; similar results were observed in the Sabiá plants concerning the spongy parenchyma. This author reports that the orelha-de-onça legume was more degraded due to the intercellular spaces in the parenchyma, favoring the colonization of microorganisms.

The vascular bundles of the Sabiá plants remained intact, having chemical and physical influence such as the presence of phenolic compounds and aerenchyma, respectively. Then, it leaded to a slow degradation of the samples with small traces of digestion in the spongy parenchyma (Figure 4B). The vascular tissues (xylem) are responsible for the low potential for particle digestion by
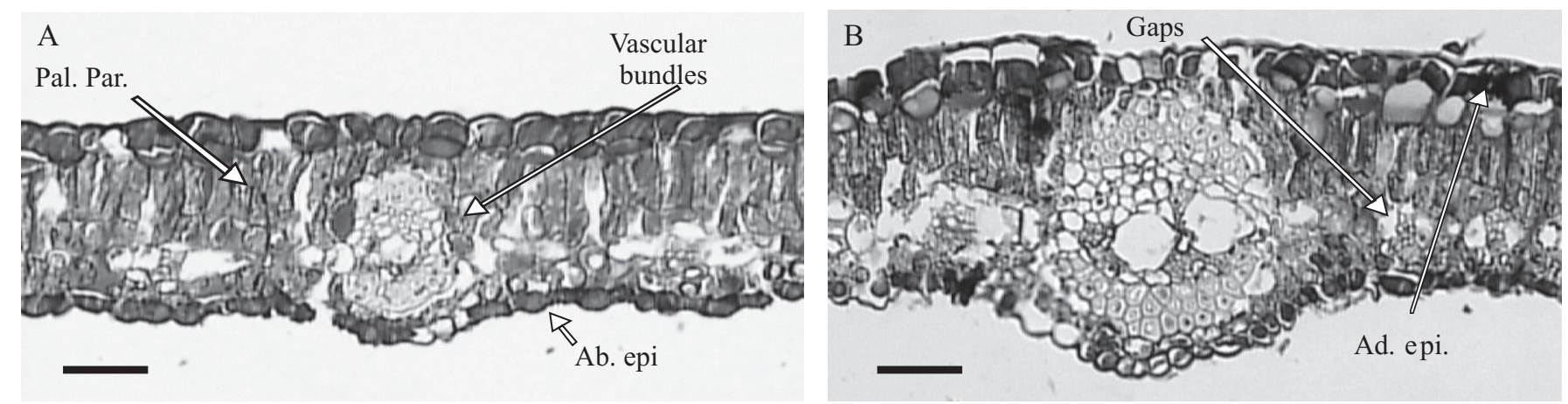

Pal. par. - palisade parenchyma; Ab. epi. - abaxial epidermis; Ad. epi. - adaxial epidermis. $\mathrm{Bar}=10 \mu \mathrm{m}$

Figure 4 - Photomicrograph of the cross section of the leaf of unincubated Sabiá plants (A) and of Sabiá plants incubated for 48 hours (B). 
the microorganisms of the rumen. Cells of these tissues, mostly thickened, are barriers to digestion, which in turn were negatively correlated with digestibility in grass. (Cabral et al., 2011).

The epidermis of the Sabiá plants presented the adaxial cell wall thicker than the abaxial cell walls, indicating that digestion occurred through the abaxial region (Figure 4A,B). This characteristic is attributed to plants that have adapted to regions where droughts occur periodically, and that, besides the thickening of the adaxial epidermis, are also highly cutinized, and present their stomata in greater proportion in the lower region of the leaf.

The location and quantification of the stomata are important because they are a gateway of microorganisms to the leaf tissues, facilitating their digestion. However, Brito et al. (1999) report that although the colonization of microorganisms via the stomata is high, this happens via chewing in a greater extent because their infestation is innermost. As in this study there was no cell disruption by chewing, all infestation by microorganisms occurred through the stomata, hindering the digestion.

The degradation of the incubated leaves of the Sabiá plants occurred in a highest proportion in the phloem tissues, due to their high digestibility and a lower proportion in the spongy parenchyma. No degradation was observed in the palisade parenchyma and xylem (Figure 4B).

Among the legumes evaluated in this study, the Sabiá plants showed the greatest degradation in relation to unincubated plants, indicating a species with greater easiness of digestion (Table 4).

The low degradation observed for the three legumes can be associated with this incubation period used in this study, which did not allow the action of microorganisms, because samples were protected by silicone tubes.

\section{Conclusions}

The legumes Mimosa caesalpiniifolia, Bauhinia cheilantha and Leucaena leucocephala have a high crude protein content and low levels of in vitro dry matter digestibility. The contents of neutral and acid detergent fiber in the Sabiá and Mororó plants are considered high and may compromise the quality of these legumes. The leaf histological characteristics of the Sabiá, Mororó and Leucena legumes are similar between the incubated and unincubated plants. The low digestibility of the legumes is caused by tissues with difficult digestion, sampling period and the incubation period evaluated.

\section{Acknowledgements}

The authors thank Instituto Agronômico de Pernambuco (IPA) and Conselho Nacional de Desenvolvimento Científico e Tecnológico ( $\mathrm{CNPq})$ for the contribution to this research.

\section{References}

AKIN, D.E. Histological and physical factors affecting digestibility of forages. Agronomy of Journal, v.81, n.1, p.17-25, 1989.

AKIN, D.E.; AMOS, H.E.; BARTON II, F.E. et al. Microbial degradation of grass tissue revealed by scanning electron microscopy. Journal of Agronomy, v.65, p.825-828, 1973.

AVIZ, M.A.B.; LOURENÇO JÚNIOR, J.B.; CAMARÃO, A.P. et al. Valor nutritivo da leguminosa Flemingia macrophylla (Willd.) Merrill para suplementação alimentar de ruminantes na Amazônia Oriental. Amazônia: Ciência e Desenvolvimento, v.4, n.8, p.253-271, 2009.

BRITO, C.J.F.A.; RODELLA, R.A.; DESCHAMPS, F.C. Anatomia quantitativa da folha e do colmo de Brachiaria brizantha (Hochst. Ex A. Rich.) Stapf. e B. humidicola (Rendle) Schweick. Revista Brasileira de Zootecnia, v.33, n.3, p.519-528, 2004.

BRITO, C.J.F.A.; RODELLA, R.A.; DESCHAMPS, F.C. et al. Anatomia quantitativa e degradação in vitro de tecidos em cultivares de capim-elefante (Pennisetum purpureum Schumach). Revista Brasileira de Zootecnia, v.28, n.2, p.223-229, 1999.

BRITO, C.J.F.A.; ALQUINI, Y.; RODELLA, R.A. Alterações histológicas de três ecotipos de capim elefante (Pennisetum purpureum Schum.), após digestão in vitro. In: REUNIÃO ANUAL DA SOCIEDADE BRASILEIRA DE ZOOTECNIA, 34., 1997, Juiz de Fora. Anais... Juiz de Fora: SBZ, 1997. v.2, p.12-14.

CABRAL, C.H.A.; BAUER, M.O.; CABRAL,C.E.A. Influência das características anatômicas e estruturais em dossel forrageiro no consumo de ruminantes. Enciclopédia Biosfera, v.7, n.13, p.680-693, 2011.

CALDAS, G.G.; SANTOS, M.V.F.; LIRA JUNIOR, M.A. et al. Caracterização morfológica e química de Mimosa caesalpinipholia a adubação com P. Archivos de Zootecnia, v.59, n.228, p.529-538, 2010.

CAVALCANTI FILHO, L.F.M.; SANTOS, M.V.F.; LIRA, M.A. et al. Caracterização de pastagem de Brachiaria decumbens na Zona da Mata de Pernambuco. Archivos de Zootecnia, v.57, n.220, p.391-402, 2008.

CHESSON, A.; STEWART, C.S.; DALGARNO, K. et al. Degradation of isolated grass mesophyll, epidermis and fibre cell wall in the rumen and by cellulolitic rumen bacteria in axemic culture. Journal Applied Bacteriology, v.60, n.4, p.327-336, 1986.

COMPANHIA PERNAMBUCANA DO MEIO AMBIENTE - CPRH. Diagnóstico socioambiental do Litoral Norte de Pernambuco. Recife, 2003. 214p.

FRANÇA, A.A.; GUIM, A.; BATISTA, A.M.V. et al. Anatomia e cinética de degradação do feno de Manihot glaziovii. Acta Scientarium Animal Science, v.32, n.2, p.131-138, 2010.

GOBBI, K.F.; GARCIA, R.; GARCEZ NETO, A.F. et al. Valor nutritivo do capim - braquiária e do amendoim forrageiro submetidos ao sombreamento. Archivos de Zootecnia, v.59, n.227, p.379-390, 2010.

GOYANNA, G.J.F. Caracterização nutricional dos fenos de Sabiá (Mimosa caesalpiniifolia Benth) e de Mororó (Bauhinia cheilantha (Bong) Steud) em caprinos. 2009. 40f. Dissertação (Mestrado em Zootecnia) - Universidade Federal Rural de Pernambuco, Recife.

HANNA, W.W.; MONSON, W.G.; BURTON, G.W. Histological examination of fresh forages leaves after "in vitro" digestion. Crop Science, v.13, n.1, p.98-102, 1973. 
HAGQUIST, C.W. Preparation and care of microscope slides. The American Biology Teacher, v.36, p.414-17, 1974.

KOZLOSKI, G.V.; PEROTTONI, J.; CIOCCA, M.L.S. et al. Potential nutritional assessment of dwarf elephant grass (Pennisetum purpureum Schum. cv. Mott) by chemical composition, digestion and net portal flux of oxygen in cattle. Animal Feed Science and Technology, v.104, p.29-40, 2003.

LEMP, B. Avanços metodológicos da microscopia na avaliação de alimentos. Revista Brasileira de Zootecnia, v.36, p.315-329, 2007 (supl. especial).

LIMA, L.M.S.; ALQUINI, Y.; BRITO, C.J.F.A. et al. Degradação ruminal dos tecidos vegetais e composição bromatológica de cultivares de Axonopus scoparius (Fluegee) Kuhlm. E Axonopus fissifolius (RADDI) Kuhlm. Ciência Rural, v.31, n.3, p.509-515, 2001.

MOREIRA, J.N.; LIRA, M.A.; SANTOS, M.V.F. et al. Caracterização da vegetação de caatinga e da dieta de novilhos no sertão de Pernambuco. Pesquisa Agropecuária Brasileira, v.41, n.11, p.1643-1651, 2006.

PACIULLO, D.S.C. Características anatômicas relacionadas ao valor nutritivo de gramíneas forrageiras. Revista Ciência Rural, v.32, p.357-364, 2002.

PACIULLO, D.S.C.; GOMIDE, J.A.; QUEIROZ, D.S. et al. Composição química e digestibilidade in vitro de lâminas foliares e colmos de gramíneas forrageiras, em função do nível de inserção do perfilho, da idade e da estação de crescimento. Revista Brasileira de Zootecnia, v.30, n.3, p.964-974, 2001.

PEREIRA, R.C.; EVANGELISTA, A.R.; ABREU, J.G. et al. Efeitos da inclusão de forragem de Leucena (Leucaena leucocephala
(Lam.) De Wit) na qualidade da silagem de milho (Zea mays L.). Ciência Agrotécnica, v.28, n.4, p.924-930, 2004.

SILVA, M.G. Dinâmica do crescimento e morfoanatomia de forrageiras nativas do Semi-árido Brasileiro. 2010. 94f. Tese (Doutorado em Zootecnia) - Universidade Federal Rural de Pernambuco, Recife.

SILVA, D.J.; QUEIROZ, A.C. Análises de alimentos (métodos químicos e biológicos). 3.ed. Viçosa, MG: Editora UFV, 2002. $235 \mathrm{p}$.

SOFFIATTI, P.; ANGYALOSSY, V. Stem anatomy of Cipocereus (Cactaceae). Bradleya, v.2, p.39-48, 2003.

TILLEY, J.M.A.; TERRY, R.A. A two stagee technique for the in vitro digestion of forage crops. Joumal of the British Grassiand Society, v.18, n.2, p.104-111, 1963.

VAN SOEST, P.J. Nutritional ecology of the ruminant. 2.ed. Ithaca: Cornell University, 1994. 476p.

VENTRELLA, M.C.; RODELLA, R.A.; COSTA, C. Anatomia e bromatologia de espécies forrageiras de Cynodon Rich. I. Folha. In: REUNIÃO ANUAL DA SOCIEDADE BRASILEIRA DE ZOOTECNIA, 34., 1997, Juiz de Fora. Anais... Juiz de Fora: Sociedade Brasileira de Zootecnia, 1997. v.2, p-3-5.

VIEIRA, E.L.; CARVALHO, F.F.R.; BATISTA, A.M.V. et al. Composição química de forrageiras e seletividade de bovinos em bosque de Sabiá (Mimosa caesalpiniifolia Benth) nos períodos secos e chuvosos. Revista Brasileira de Zootecnia, v.34, n.5, p.1505-1511, 2005.

WILSON, J.R. Organization of forage plant tissues. In: JUNG, H.G., BUXTON, D.R. et al. (Eds.) Forage cell wall structure and digestibility. Madison: ASA/CSSA/SSSA, 1993. p.1-32. 